\title{
Oligometastases of Gastrointestinal Cancer Origin
}

\author{
Nancy E. Kemeny ${ }^{\mathrm{a}}$ Beate Rau ${ }^{\mathrm{b}}$ \\ a Department of Medicine, Gastrointestinal Oncology Service, Memorial Sloan Kettering Cancer Center, New York, NY, USA; \\ ${ }^{b}$ Department of General Surgery, Campus Virchow and Mitte, Charité - Universitätsmedizin Berlin, Berlin, Germany
}

In 1889, Paget proposed a 'seed-soil' hypothesis to explain the pathogenesis of metastasis. This hypothesis stated that 'seeds are carried in all directions; but they can only live and grow in congenial soil' [1]. Cancer cells have to undergo a multistep process to reach metastatic potential, finally forming metastasis at distant organs, and more information on the pattern and evolution of metastases is needed [2-6]. Later investigators demonstrated that while metastatic cells may reach a number of organs, metastases developed in a select few and for some there are only oligometastases $[2,7]$.

A variety of techniques is employed for the control of oligometastatic disease. Surgery is the most important treatment modality for oligometastasis. New laparoscopic equipment enables the surgeon now to perform metastasectomy by minimally invasive techniques, which is much more attractive for patients [8]. This is clear in colon cancer but not so evident in other gastrointestinal cancers. Selected patients with synchronous and metachronous oligometastatic disease may potentially benefit from a surgical resection with an acceptable morbidity [8-11]. Resection of peritoneal metastases and intraperitoneal treatment have been carried out successfully $[12,13]$. Current evidence suggests that percutaneous ablation also improves oncologic outcomes in some patients in combination with chemotherapy $[14,15]$.

Despite the traditional radioresistance associated with solid tumors, modern dose-escalated stereotactic body radiation therapy
(SBRT) regimens are able to overcome this and achieve high rates of local control [16-19]. Additionally, exciting work is underway to investigate the immunomodulatory effects of SBRT in conjunction with immunotherapeutics in patients with oligometastatic disease [20].

The development of new drugs and interventional devices has provided platforms to design new treatment algorithms for patients with oligometastasis. Whereas decades ago metastatic disease meant palliative care, new technical treatments may lead to longtime survival in selected patients. Advances in systemic therapy also extended the survival of patients with metastatic disease [21], rendering effective local therapy of increasing importance.

Locoregional chemotherapy such as hepatic arterial infusion (HAI) plays a role in treating hepatic metastases from colorectal cancer in both the resectable and unresectable setting [22-26]. For patients with unresectable metastases to the liver, HAI can be used with systemic chemotherapy to achieve increased response rates even in patients after progression on first- and second-line chemotherapy [27]. Results show increased response and conversion to resection with the use of HAI and systemic therapy versus systemic therapy alone.

The future is certainly better for patients with cancer, even with metastatic disease, and especially for patients with oligometastatic disease.

\section{References}

1 Paget S: The distribution of secondary growths in cancer of the breast. 1889. Cancer Metastasis Rev 1989;8: 98-101.

2 Chambers AF, Groom AC, Macdonald IC: Dissemination and growth of cancer cells in metastatic sites. Nat Rev Cancer 2002;2:563-572.

3 Valastyan S, Weinberg RA: Tumor metastasis: molecular insights and evolving paradigms. Cell 2011;147: 275-292.

4 Malladi S, Macalinao DG, Jin X, He L, Basnet H, Zou Y, de Stanchina E, Massague J: Metastatic latency and immune evasion through autocrine inhibition of WNT. Cell 2016;165:45-60.
5 Holch JW, Demmer M, Lamersdorf C, Michl M, Schulz C, von Einem JC, Modest DP, Heinemann V: Pattern and dynamics of distant metastases in metastatic colorectal cancer. Visc Med 2017;33:DOI: 10.1159/ 000454687.

6 Pachmayr E, Treese C, Stein U: Underlying mechanisms for distant metastasis - molecular biology. Visc Med 2017;33:DOI: 10.1159/000454696.

7 Hart IR, Fidler IJ: Role of organ selectivity in the determination of metastatic patterns of B16 melanoma. Cancer Res 1980;40:2281-2287.
8 Aigner F, Pratschke J, Schmelzle M: Oligometastatic disease in colorectal cancer - how to proceed? Visc Med 2017;33:DOI: 10.1159/000454688.

9 Adam R, De Gramont A, Figueras J, Guthrie A, Kokudo N, Kunstlinger F, Loyer E, Poston G, Rougier P, Rubbia-Brandt L, Sobrero A, Tabernero J, Teh C, Van Cutsem E; Jean-Nicolas Vauthey of the EGOSLIM (Expert Group on OncoSurgery management of LIver Metastases) group: The oncosurgery approach to managing liver metastases from colorectal cancer: a multidisciplinary international consensus. Oncologist 2012;17: 1225-1239.

\section{KARGER}

(๑) 2017 S. Karger GmbH, Freiburg

Fax +497614520714 
10 Chiapponi C, Berlth F, Plum PS, Betzler C, Stippel DL, Popp F, Bruns CJ: Oligometastatic disease in upper gastrointestinal cancer - how to proceed? Visc Med 2017;33:DOI: 10.1159/000455683.

11 Renz BW, Boeck S, Roeder F, Trumm C, Heinemann $\mathrm{V}$, Werner J: Oligometastatic disease in pancreatic cancer - how to proceed? Visc Med 2017;33:DOI: 10.1159/ 000455027.

12 Sugarbaker PH: Intraperitoneal chemotherapy and cytoreductive surgery for the prevention and treatment of peritoneal carcinomatosis and sarcomatosis. Semin Surg Oncol 1998;14:254-261.

13 Rau B, Brandl A, Pascher A, Raue W, Sugarbaker P. Oligometastatic disease in the peritoneal space with gastrointestinal cancer. Visc Med 2017;33:DOI: 10.1159/ 000454694.

14 Ruers T, Punt C, Van Coevorden F, Pierie JP, BorelRinkes I, Ledermann JA, Poston G, Bechstein W, Lentz MA, Mauer M, Van Cutsem E, Lutz MP, Nordlinger B; EORTC Gastro-Intestinal Tract Cancer Group, Arbeitsgruppe Lebermetastasen und -tumoren in der Chirurgischen Arbeitsgemeinschaft Onkologie (ALM$\mathrm{CAO}$ ) and the National Cancer Research Institute Colorectal Clinical Study Group (NCRI CCSG): Radiofrequency ablation combined with systemic treatment versus systemic treatment alone in patients with non-resectable colorectal liver metastases: a randomized EORTC Intergroup phase II study (EORTC 40004). Ann Oncol 2012;23:2619-2626.

15 Petre EN, Sofocleous C: Thermal ablation in the management of colorectal cancer patients with oligometastatic liver disease. Visc Med 2017;33:DOI: 10.1159/ 000454697.
16 McGarry RC, Papiez L, Williams M, Whitford T, Timmerman RD: Stereotactic body radiation therapy of early-stage non-small-cell lung carcinoma: phase I study. Int J Radiat Oncol Biol Phys 2005;63:10101015.

17 Norihisa Y, Nagata Y, Takayama K, Matsuo Y, Sakamoto T, Sakamoto M, Mizowaki T, Yano S, Hiraoka M: Stereotactic body radiotherapy for oligometastatic lung tumors. Int J Radiat Oncol Biol Phys 2008;72: 398-403.

18 Yamada Y, Bilsky MH, Lovelock DM, Venkatraman ES, Toner S, Johnson J, Zatcky J, Zelefsky MJ, Fuks Z: High-dose, single-fraction image-guided intensitymodulated radiotherapy for metastatic spinal lesions. Int J Radiat Oncol Biol Phys 2008;71:484-490.

19 Wild AT, Yamada Y: Treatment options in oligometastatic disease: stereotactic body radiation therapy focus on colorectal cancer. Visc Med 2017;33:DOI: 10.1159/000454685.

20 Postow MA, Callahan MK, Barker CA, et al: Immunologic correlates of the abscopal effect in a patient with melanoma. N Engl J Med 2012;366:925-931.

21 Kopetz S, Chang GJ, Overman MJ, Eng C, Sargent DJ, Larson DW, Grothey A, Vauthey JN, Nagorney DM, McWilliams RR: Improved survival in metastatic colorectal cancer is associated with adoption of hepatic resection and improved chemotherapy. J Clin Oncol 2009;27:3677-3683.

22 Kemeny N, Huang Y, Cohen AM, Shi W, Conti JA, Brennan MF, Bertino JR, Turnbull AD, Sullivan D, Stockman J, Blumgart LH, Fong Y: Hepatic arterial infusion of chemotherapy after resection of hepatic metastases from colorectal cancer. N Engl J Med 1999; 341:2039-2048.
23 Kemeny NE, Gonen M: Hepatic arterial infusion after liver resection. N Engl J Med 2005;352:734-735.

24 D’Angelica M, Correa-Gallego C, Paty P, Cercek A, Gewirtz A, Chou JF, Marinella Capanu M, Kingham TP, Fong Y, DeMatteo RP, Allen PJ, Jarnagin WR, Kemeny N: Phase II trial of hepatic artery infusional and systemic chemotherapy for patients with unresectable hepatic metastases from colorectal cancer: conversion to resection and long-term outcomes. Ann Surg 2015; 261:353-360.

25 Ducreux M, Ychou M, Laplanche A, Gamelin E, Lasser P, Husseini F, Quenet F, Viret F, Jacob JH, Boige V, Elias D, Delperro JR, Luboinski M; gastrointestinal group of the Federation Nationale des Centres de Lutte Contre le Cancer: Hepatic arterial oxaliplatin infusion plus intravenous chemotherapy in colorectal cancer with inoperable hepatic metastases: a trial of the gastrointestinal group of the Federation Nationale des Centres de Lutte Contre le Cancer. J Clin Oncol 2005; 23:4881-4887

26 Zervoudakis A, Boucher T, Kemeny N: Treatment options in colorectal liver metastases: hepatic arterial in fusion. Visc Med 2017;33:DOI: 10.1159/000454693.

27 Cercek A, Boucher TM, Gluskin J, Aguilo A, Chou JF, Connell LC, Capanu M, Reidy-Lagunes D, D’Angelica $\mathrm{M}$, Kemeny NE: Response rates of hepatic arterial infusion pump therapy in patients with metastatic colorectal cancer liver metastases refractory to all standard chemotherapies. J Surg Oncol 2016;114:655-663. 